\title{
VERBAL STRATEGIES USED IN OPENING A CONVERSATION IN OFFICE SETTINGS BY ENGLISH AND VIETNAMESE STAFF AND MANAGERS
}

\author{
Hoang Tra My* \\ Mien Trung University of Civil Engineering, Nguyen Du, Tuy Hoa, Phu Yen, Vietnam
}

Received 31 March 2017

Revised 09 November 2017; Accepted 27 November 2017

\begin{abstract}
In interaction, an appropriate opening may help participants create good impression on their interlocutors and make the conversation more effective; however, producing a polite and smooth opening may be a remarkably challenging task. The study, therefore, aims at yielding insights into the process of conversational opening with focus on the description of verbal strategies. The collected data are 60 English and 60 Vietnamese opening sections in scripted dialogues between staff and managers. The method of qualitative content analysis is applied to expose categories of verbal strategies emerging from the data. The results reveal that, compared with English subjects, Vietnamese ones create a much lengthier opening with the use of more number of verbal strategies. Especially, through the process of opening a conversation, English subjects display a formal relationship with work-oriented exchanges whilst Vietnamese ones show a close but respectful relationship with rapport-oriented exchanges.

Keywords: conversational opening, verbal strategies, content analysis, opening strategies, conversational opening strategies
\end{abstract}

\section{Introduction}

Behaving appropriately, politely and effectively in face-to-face interaction with others is extremely essential because, for a long time, people have employed faceto-face interaction to create, re-create and maintain social relationship (Goffman, 1963; Kendon, 1977; Maynard \& Zimmerman, 1984; Schegloff, 1986). However, it is rather challenging for many people to produce a smooth conversation, especially the opening process. Opening a conversation in one's mother tongue is difficult, and it becomes even more difficult and exceedingly challenging in a foreign language due to language and cultural diversity. With the aim to find out verbal opening strategies utilized by English and Vietnamese subjects, the study seeks answers to two research questions, (1)

${ }^{*}$ Tel.: 84-977046680

Email: hoangtramy.hn@gmail.com what verbal strategies are used by English and Vietnamese staff and managers to open a conversation in office settings? and (2) how are these verbal strategies employed by English and Vietnamese staff and managers to open a conversation in office settings?

\section{Theoretical background}

To examine conversational opening strategies, it is vital to clarify the meaning of the concept "opening". Although many investigators have used the term "opening" in interchange with the term "greeting" (Omar, 1989; Youssouf, Grimshaw \& Bird, 1976; Firth, 1972; Kendon \& Ferber, 1973; Duranti, 1992), these two concepts are definitely different. Greeting can be an initial part of a conversation or just a ritual exchange or a passing-by salutation which may or may not be followed by further conversational moves while opening is always the first part of a conversation. Conversational opening occurs 
when a speaker wants to raise a topic for discussion and it may include greeting as one of its parts (Schegloff, 1968). Conversational opening, in this study, is understood as the initial part of a conversation, beginning from the participants' gathering to the initiation of the first topic of concern.

Historically, Schegloff (1968) is regarded as the pioneer and groundbreaker in the field of conversational opening with his research conducted on 500 telephone calls. After that, numerous researchers around the world have drawn their keenness in this area. Among them, Krivonos and Knapp (1975), Duranti (1992), Schiffrin (1977), Omar (1992) and Pillet-Shore (2008) are remarkable in their approach to the area of conversational opening in various aspects. With the aim to compare conversational openings between acquainted and non-acquainted participants, Krivonos and Knapp (1975) introduce categories of verbal and non-verbal greeting behaviors. The verbal and non-verbal behaviors are ranked and analyzed in terms of the frequency of occurrence and then the effects of acquaintanceship on greetings are drawn out and assessed. Also approaching participants' verbal and nonverbal behaviors in greetings, Duranti (1992, p. 663) claims that verbal content changes from one language to another and from one situation to another within the same language, which creates numerous obstacles for partners coming from different cultures in interaction. According to him, a conversation can be typically opened with the physical or spiritual well-being of the interactants such as "how are you?" or "may peace/ God/ health be with you" (Duranti, p. 663). Particularly keen on social organization of opening encounters, Schiffrin (1977), in his dissertation, suggests a base form for opening sequences. From his base form, various adaptations are introduced and applied to particular situations. Unlike Krivonos and
Knapp (1975) and Schiffrin (1977), Omar (1992) and Pillet-Shore (2008) examine conversational opening from pragmatic and conversation analysis perspectives respectively. From pragmatic perspective, Omar (1992) investigates conversational opening in Kiswahili performed by native and non-native speakers and concludes that the opening in Kiswahili is lengthy and often includes several phatic inquiries and phatic responses (p. 18). From conversation analysis perspective, Pillet-Shore (2008), in her dissertation, concentrates on the process of creating and maintaining social relationships through the opening of face-to-face interactions. She employs naturally occurring video- and audio-recorded encounters as the data for analysis. Especially, both verbal and body-behavioral aspects performed by the acquainted and non-acquainted in opening sections of face-to-face conversations are explored in the scope of her research.

Whilst the field of conversational opening flourishes with various studies around the world, it has hardly seen any scholarly interest in Vietnam with the exception of an M.A thesis of Tram (2002). This thesis laid foundation for this area by comparing English and Vietnamese conversational opening in the light of pragmatics. The study starts with examining strategies used to open a conversation and then it draws out similar and different pragmatic aspects of conversational opening in English and Vietnamese based on the analysis of data collected from various sources like textbooks, listening tapes and films.

This study of mine hopes to help lessen such scarcity of conversational research in the country, especially conversational openings in office settings, and following is how the study was conducted.

\section{Methodology}

The present study makes use of scripted conversations as the data for analysis. The 
exploitation of scripted conversations instead of naturally occurring ones is due to two reasons. For the first reason, the process of recording natural conversations in office settings is infeasible. In offices, business information must be kept confidential so any attempts to secure consent are likely to be rejected. Additionally, putting recorders in offices without permission is regarded as illegal unless this bugging is allowed by the court or police or the like for criminal or similar investigation. For the second reason, despite the artificiality of film and soap dialogues, scripted conversations strongly resemble natural conversations. The language of television is a reflection or representative of real conversations because it is normally written by skilled scriptwriters, with their underlying cultural background knowledge, enacted by professional actors and/or actresses who, with their own talents, try to perform as exactly as in real life and accepted by viewers.

The data of the present study include 120 conversations (60 English and 60 Vietnamese). To achieve equivalent contents and forms, English and Vietnamese films selected have to follow some common criteria such as broadcast channels, production time and contexts. From these criteria, two English films - "House of cards" and "Suits", and five Vietnamese films - "Đối thủ kỳ phùng", "Cảnh sát hình sự - Chạy án", "Lập trình cho trái tim", "Mưa bóng mây" and "Câu hỏi số 5" are selected. These films discuss current social issues in official contexts such as working environments of businessmen, politicians, congressmen, and police. Similar features of these films can enhance the validity and reliability of data collected from them. From the chosen films, conversations are gathered. Selected conversations must have opening sections and be between two participants - a staff and a manager aged from 20 to 60 .

In terms of data analysis procedure, the method of qualitative content analysis is utilized to analyze the collected data. The data are coded inductively. Any verbal strategies occurring in the data are noted down and then these strategies are grouped into appropriate categories regarding similar features. In other words, with the method of qualitative content analysis, the researcher allows the categories to flow from the data and new insights to emerge or patterns are constructed inductively. After this stage, the categories of verbal strategies employed by English and Vietnamese subjects are built. Then, the frequency of occurrence of each strategy is calculated in relation with 60 collected conversations. Based on the frequency of occurrence, the process of comparing and contrasting between English and Vietnamese subjects can be conducted. Finally, in the findings and discussions part, verbal strategies performed by English and Vietnamese staff and managers are deliberated from the most to the least popular ones regarding their frequency of occurrence in relation with 60 collected conversations.

\section{Findings and discussions}

4.1. Verbal strategies by English and Vietnamese subjects

The findings indicate that English and Vietnamese subjects utilize 16 categories of verbal strategies to open a conversation in office settings. The distribution of each group of strategies in English and Vietnamese is significantly different. The occurrence of these categories is illustrated in Table 1. 
Table 1. Verbal strategies by English and Vietnamese subjects

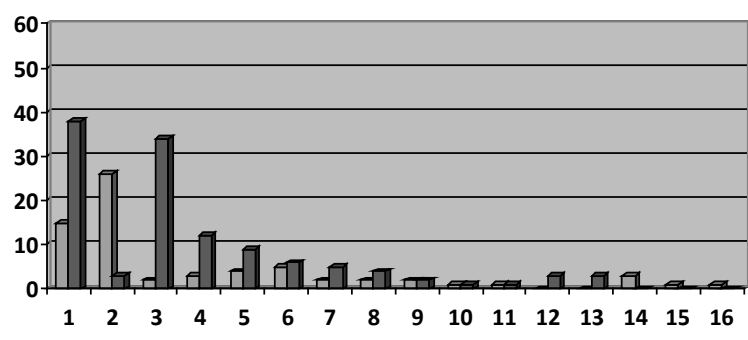

$\square$ English $\square$ Vietnamese

Notes:

\begin{tabular}{|c|c|}
\hline $\begin{array}{l}\text { 1: Greeting } \\
\text { 2: Calling the other's } \\
\text { name/ title } \\
\text { 3: Initiating the topic } \\
\text { 4: Inviting the other to } \\
\text { sit down } \\
\text { 5: Referring to the } \\
\text { other's state } \\
\text { 6: Talking about } \\
\text { previous task/ action } \\
\text { 7: Offering the other } \\
\text { some wine/ tea } \\
\text { 8: Asking confirmation } \\
\text { question }\end{array}$ & $\begin{array}{l}\text { 9: Talking about current } \\
\text { task } \\
\text { 10: Referring to external } \\
\text { circumstances/ } \\
\text { objects } \\
\text { 11: Apologizing } \\
\text { 12: Referring to self } \\
\text { 13: Talking about life at } \\
\text { home } \\
\text { 14: Asking for the } \\
\text { other's availability } \\
\text { for talking } \\
\text { 15: Talking about the } \\
\text { third person } \\
\text { 16: Offering help }\end{array}$ \\
\hline
\end{tabular}

Table 1 illustrates a considerable difference in the use of verbal strategies by English and Vietnamese subjects to open a conversation in office settings. In general, compared with English subjects, Vietnamese ones are inclined to produce a lengthier opening with more number of verbal strategies. Factually, the total number of verbal strategies exploited by Vietnamese staff doubles that of English ones with 150 and 76 respectively. On average, Vietnamese subjects make use of more than two verbal strategies while English subjects only need one strategy to open a conversation in office settings. Specifically, the ways English and Vietnamese subjects employ each strategy to initiate a conversation are different. To depict the similarities and differences in the ways English and Vietnamese subjects open a conversation verbally, strategies are analyzed regarding their frequency of occurrence.

\subsection{The most frequently used strategies by} English and Vietnamese subjects

It is revealed from the findings that three strategies including greeting, calling the other's name/ title and topic initiation are most frequently used by English and Vietnamese subjects. Whereas the strategy of greeting is preferred by both subjects, the strategy of calling the other's name/ title is chosen by English subjects and the strategy of topic initiation is selected by Vietnamese ones. The employment of these three strategies can account for the most common ways of initiating a conversation in office settings.

Firstly, the strategy of greeting occurs in 38 Vietnamese conversations, accounting for $63.3 \%$ and 12 English conversations, making up $25 \%$. Its extremely high frequency of occurrence in Vietnamese conversations can be attributed to the culture of greeting. According to Phạm Văn Tình (2000, p. 225), Vietnamese people highly appreciate "greeting" because it has a big role in initiating a conversation and it influences the rest of the conversation. For this reason, greeting seems to appear in every Vietnamese conversation. In Vietnamese, a greeting utterance is constructed by the following components:

\begin{tabular}{|c|c|c|c|c|c|}
\hline Formula & $\begin{array}{c}\text { Polite particle } \\
\text { (Dạ) }\end{array}$ & $\begin{array}{c}\text { Subject } \\
\text { (chủ thể) }\end{array}$ & $\begin{array}{c}\text { "greet" } \\
\text { (chào) }\end{array}$ & $\begin{array}{c}\text { object } \\
\text { (đối tượng chào) }\end{array}$ & $\begin{array}{c}\text { polite particle } \\
\text { (ạ) }\end{array}$ \\
\hline \multirow{2}{*}{ Examples } & Dạ, & cháu & chào & chú & ạ \\
& Dạa & em & chào & anh & ạ \\
\hline
\end{tabular}


Normally, Vietnamese subjects produce a greeting utterance by using one or combining several components or all components above depending on the level of intimacy as well as social status between interlocutors. The most common structure of greeting is produced by the combination of the verb "Chào" (greet) plus an object (đối tượng chào). The object (đối tượng chào) can be addressed in two ways, either by kinship terms or titles. Accordingly, the most common greeting structures are (1) "Greet" (chào) + a kinship term and (2) "Greet" (chào) + a title. Depending primarily on the gap of age between interlocutors, different kinship terms are chosen, for example, chú (uncle), bác (uncle), cô (aunt), anh (elder brother), chi (elder sister), em (younger sister), cháu (niece - nephew), etc. Kinship terms are normally used between or among relatives. However, when these terms are used by staff and managers in offices, they make the relation between interlocutors closer and consequently help the conversation to be more effective.

Instead of using kinship terms, a speaker can perform a greeting utterance by combining the verb Chào with a title which refers to the hearer's social status. Some typical titles commonly used in offices are sếp (boss), thu trương (boss), giám đốc (manager), tổng giám đốc (managing director), etc. The occurrence of these titles in the examined conversations is due to the office settings and parties' relationships. The findings show that social titles tend to be employed by the persons of lower status - the staff towards the persons of higher status - the managers as a way of expressing the respect of a person in lower position towards a person of higher position.

Additionally, in combination with kinship terms or titles, polite particles " $d a$ " may also be added at the beginning and " $a$ " at the end of a greeting utterance to make the greeting more polite and respectful. For example, in
(1), a Vietnamese staff greets his manager by using the kinship term "Em" (younger brother) to refer to the subject himself and "Anh" (elder brother) to refer to the object (his interlocutor) in combination with the polite particles "ạ" (yes) at the beginning and "dạ" (yes) at the end of the utterance. Thanks to the combination of the kinship term and polite particles, the greeting utterance appears both close and respectful.
(1) Staff:
(Knock at door)
Manager:
Mời vào!
"Come in!"

Staff:

\section{Dạ, em chào anh ạ!}

$\mathrm{PoP}^{(1)}$ younger brother

greet elder brother PoP

"Hello, brother."

[Đối thủ kỳ phùng, episode 8 - 27:50]

In some cases, a greeting utterance can also be performed without the verb "Chào" (greet). Speakers may greet simply by calling out the kinship terms referring to the object (đối tượng chào) or kinship terms plus his/ her name. Speakers may also use polite particles " $d a$ " (yes) at the beginning and/or " $a$ " (yes) at the end of the utterance to increase politeness in interaction. For example, in (2), a staff greets his manager with a kinship term combined with the polite particle " $a$ " (yes):

$\begin{array}{lll}\text { (2) Staff: } & \text { Chú } & \text { a. } \\ & \text { Uncle } & \text { PoP } \\ & \text { "Hello." } & \end{array}$

[Cảnh sát hình sự - Chạy án, season 1, episode 3 - 10:38]

Whilst greeting strategy occurs extremely frequently in Vietnamese, it only appears in 12 English conversations. Furthermore, the ways of greeting by English subjects are rather simple in comparison with those of Vietnamese ones. The most common

\footnotetext{
${ }^{1}$ PoP stands for polite particle in Vietnamese. From now on, to save space, we will mostly give the literally, roughly-equivalent English translation of the Vietnamese examples. Gloss is provided only when highly necessary.
} 
formulaic expression of greeting used by English subjects is "Hi/ Hello" + "first name". This formulaic expression is employed by an English manager in greeting in example (3) below:

(3) Manager: Hello, Nancy.

Staff: Welcome back, sir. Linda Vasquez called for you

[House of cards, season 1, episode 3-47:26]

Besides the use of "Hi/ Hello", English subjects also greet each other with the expression of the time of the day. An English greeting utterance can be constructed as "Good morning/ afternoon/ evening" + "first name"/ "title". The findings further display that first names are usually employed by managers whereas titles are often used by staff. This difference may be justified by the power distance between two interlocutors. Normally, calling out the partner's first name expresses the closeness and power while calling out the partner's title shows respect and negative politeness.

The results indicate that greeting strategy is notably different in English and Vietnamese in terms of its frequency of occurrence and its formulaic structures. Compared with greeting utterances in English, those in Vietnamese appear to be more complicated with regard of various aspects such as appropriate choices of kinship terms, titles and polite particles (dạ)/ (a). Especially, the use of kinship terms and polite particles (da)/ (a) is rather typical in Vietnamese greetings whilst these terms do not occur in English greetings among my data. The occurrence of these terms in Vietnamese greeting may be accounted as a way to express politeness among parties.

Secondly, while Vietnamese subjects prefer greeting, English subjects are inclined to call the other's title/ name to get the other's attention. Calling the other's name/ title is the most favorite strategy of English subjects with its occurrence in 26 conversations, accounting for $43 \%$. In contrast, it occurs in only three
Vietnamese conversations, making up 5\%. This strategy can be seen as a way for parties to get attention from their interlocutors and open a conversation as quickly as possible. Especially, calling out the title is often employed by staff as a way to express their respect whereas calling out the first name is normally used by managers as a way to show closeness and intimacy.

Instead of calling the other's name or title like English subjects, Vietnamese subjects tend to choose different kinship terms to address their interlocutors. For example, in (4), a Vietnamese staff calls his manager by the kinship term "Anh" (brother) while in (5), an English manager greets his assistant just by calling out his first name.

$\begin{array}{ll}\text { (4) Staff: } & \begin{array}{l}\text { Anh! } \\ \text { "Brother!" }\end{array} \\ \text { Manager: } & \begin{array}{l}\text { Ù'. } \\ \text { "Yes." }\end{array} \\ \text { Staff: } & \begin{array}{l}\text { Công ty Hoàng Quân đang có } \\ \text { cuộc đình công to lắm. } \\ \text { "There is a very big strike in }\end{array} \\ & \text { Hoang Quan Company." }\end{array}$ 8 - 24:22]

(5) Staff: (Knock at door and open the door) Manager: Meechum.

[House of cards, season 2, episode 10 - 25:03]

Lastly, the strategy of topic initiation is present in 34 Vietnamese conversations with $56.7 \%$ but it occurs in only two English conversations, accounting for $3.3 \%$. In Vietnamese, this strategy is regarded as an assistance for the topic of concern to be raised smoothly. Topic initiation strategy is typically performed by the utilization of a performative verb combined with an object. Regarding performative verbs, basing on the content of the topic which is going to be raised, the initiators of the conversation choose appropriate performative verbs to help their interlocutors catch the topic easily. The findings expose that Vietnamese staff 
and managers employ different categories of performative verbs. Some typical performative verbs used by Vietnamese staff such as báo cáo (report), trình bày (present) and tranh thủ $\dot{y}$ kiến (ask) and some others exploited by Vietnamese managers like vào chuyện (begin), bàn (discuss) and thông báo (inform). The difference in the choice of verbs is due to the difference of social status because through the verb choice, staff express respect but managers show power on their interlocutors.

In addition, parties can choose kinship terms or titles to address the objects. As normal, staff and managers choose different kinds of kinship terms or titles because of the power distance between them. If this strategy is utilized by staff, the particle (da) is often put at the beginning of the utterance. For example, in (6), the employment of the particle $(d a)$ increases the degree of politeness of the utterance whilst the utilization of the kinship term "chu'" (uncle) referring to the object - the manager - makes the relationship between them more intimate.

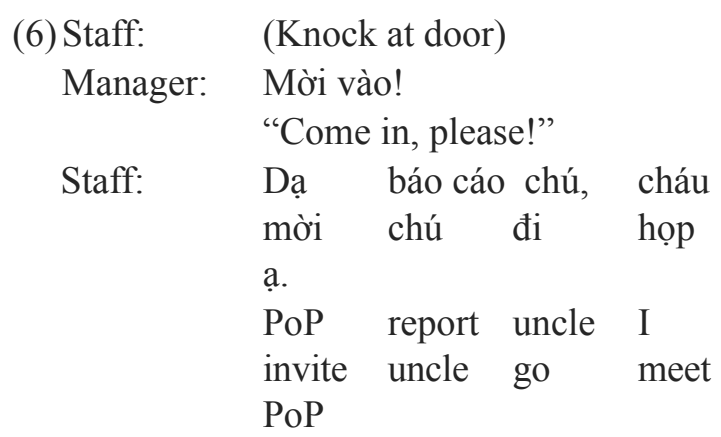

"It is time for you to attend the meeting."

[Đối thủ kỳ phùng, episode 26 - 5:41]

4.3. The less frequently used strategies by English and Vietnamese subjects

In connection with the group of less popular strategies, five strategies including inviting the other to sit down, offering tea/ wine, referring to the other's state and talking about previous task/ action are occasionally utilized by both subjects in initiating a conversation in office settings. Firstly, the strategies of inviting the other to sit down and offering tea/ wine appear in twelve and five Vietnamese conversations $(20 \%$ and $8.3 \%$ ) but only occurs in three (5\%) and two English conversations (3.3\%). The rather high frequency of occurrence of these two strategies in Vietnamese conversations may be explained by the low pace of interaction in this culture. It can be inferred that Vietnamese subjects do not initiate the topic of concern right after they get the other's attention or right after they greet each other. Instead, they are inclined to exchange some phatic communication with some polite or ritual behaviors such as inviting the others to come in, to sit down and to drink some tea. The act of inviting the other to sit down is rather typical in Vietnamese culture and as observed from the data, Vietnamese subjects are inclined to sit rather than stand while discussing matters which take time to finish. Inversely, in quick exchanges, such as presenting files or informing of the guest's coming, the strategy of invitation to sit down is unnecessary. The staff may have a quick conversation and then leave the room. In example (7) below, the strategy of inviting the other to sit down is utilized by the manager before he initiates the main topic of concern with his staff.
(7) Staff:
(Knock at door)
Manager:
Mời vào!
"Come in, please!"
Staff: Dạ em chào anh ạ.

Manager: Cậu ngồi đi. Kế này, chuyện hôm nọ cậu đánh thằng $\mathrm{Cư}$ xảy ra chuyện lớn rồi.

"Sit down. Ke, that you bit $\mathrm{Cu}$ last time caused a big problem."

[Đối thủ kỳ phùng, episode 8 - 27:50]

Especially, the strategy of inviting the other to sit down is often followed by the strategy of offering drink. By offering the other party some tea or water, Vietnamese 
subjects express politeness, enhance closeness with their interlocutors and take time to find appropriate strategies to raise the topic of concern. Let's look at example (8) below.

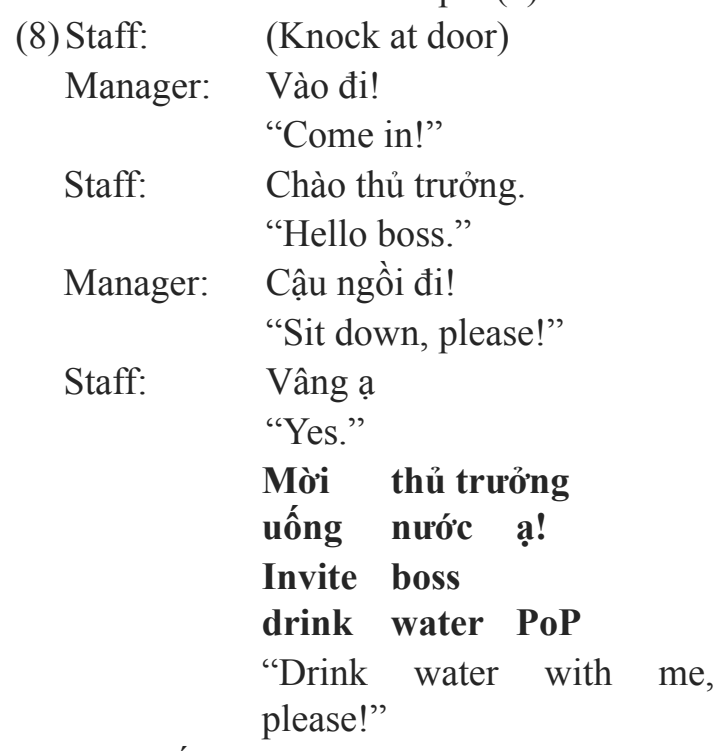

[Câu hỏi số 5, episode 7 -20:00]

In example (8), the manager invites the staff to come in, to sit down, then he pours tea into a cup to offer the staff. The manager accomplishes the act of inviting the staff to drink nonverbally. However, when the staff takes the cup of tea to drink, he invites the manager to drink together. This act is not actually an invitation but just a Vietnamese ritual behavior and also a way of thanking for the offer. Habitually, before eating or drinking, Vietnamese people often produce a ritual invitation as a way to inform their interlocutors that they are going to eat or drink. With this way of informing, Vietnamese people express politeness towards their interlocutors. The acts of invitation of sitting and drinking can be regarded as phatic communication which are just to enhance and promote the relationship between interlocutors. From the literature review, it can be seen that the opening sections in Vietnamese are like ones in Kiswahili which are lengthy and often include several phatic inquiries and phatic responses (Omar, 1992, p. 18).

In contrast, the infrequent occurrence of the strategies of inviting the other to sit down and offering the other tea/ wine in English conversations may be due to the fast pace of English interaction. Habitually, English subjects intend to lead in the main topic as soon as possible, often right after they get the other's attention. Hence, the acts of inviting the other to sit or drink appear unnecessary and ineffective in interaction in office settings. Specifically, the data also reveal that unlike Vietnamese subjects, English subjects often stand to exchange information with their partners regardless their partners are standing or sitting. Furthermore, instead of inviting their interlocutors to drink tea or coffee like Vietnamese subjects, English ones may invite them other beverages, for instance, Whiskey, as illustrated in example (9).

(9) Manager: Drink?

Staff: Sure, what do you get?

Manager: Whiskey. Blends.

Staff: If you're offering.

Manager: So, how are things in the City of Brotherly Love?

[House of cards, season 1, episode 1-44:29]

Secondly, the strategy of referring to the other's state occurs in nine Vietnamese conversations (15\%) and four English conversations (6.7\%). This strategy is employed to express concern towards the others. However, its usage is a bit different between English and Vietnamese subjects. Although English subjects make use of this strategy to show regards towards their interlocutors, it is not because they care about them, but because their current state influences the common task. For example:

(10) Staff: Jesus, Peter. What happened? You're drunk.

Manager: I'm fine.

Staff: I can smell it on you.

Manager: $\quad$ Okay, I had a drink or two.

It was nothing crazy.

Staff: We can't do this interview.

[House of cards, season 1, episode 10 - 43:02] 
As depicted in example (10), the staff refers to his manager's state by confirming that he is drunk. However, the purpose of the staff is not to express the concern or care about his manager's health. He cares about his manager's state just because the manager's bad state may create bad effects on the interview which he is going to take. In contrast, Vietnamese subjects exploit this strategy just to express concern and care about their interlocutors as in example (11) below:

\begin{tabular}{|c|c|}
\hline (11) Staff: & (Knock at door) \\
\hline Manager: & Vào đi! \\
\hline & “Come in!” \\
\hline Staff: & $\begin{array}{l}\text { Chào thủ trưởng. } \\
\text { "Hello boss." }\end{array}$ \\
\hline Manager: & $\begin{array}{l}\text { Cậu ngồi đi! } \\
\text { "Sit down, please!" }\end{array}$ \\
\hline Staff: & $\begin{array}{l}\text { Vâng ạ. } \\
\text { "Yes." } \\
\text { Mời thủ trưởng uống nước ạ. } \\
\text { "Drink water with me, please" }\end{array}$ \\
\hline Manager: & $\begin{array}{l}\text { Tay cậu sao rồi? } \\
\text { "Is your hand better?" }\end{array}$ \\
\hline Staff: & $\begin{array}{l}\text { Đạn chỉ sượt qua thôi ạ } \\
\text { "Just a small wound." }\end{array}$ \\
\hline Manager: & $\begin{array}{l}\text { Do Linh công tử làm? } \\
\text { "Shot by Linh?" }\end{array}$ \\
\hline
\end{tabular}

[Câu hỏi số 5, episode 7 -20:00]

It can be seen from example (11) that after several exchanges of greeting, invitation of sitting down and invitation of drinking, the manager expresses his concern towards his staff by asking about the wound on his hand. Thanks to his regard, the staff feels better and their relationship becomes closer. The effectiveness of the conversation, accordingly, is enhanced.

Finally, the strategy of talking about previous task/ action appears rather equally in the two languages. It is present in six Vietnamese conversations (10\%) and five English ones $(8.3 \%)$. The employment of this strategy is due to the typical settings and particular relationship in which the conversations occur. The examined conversations take place in office settings between a staff and his/ her manager; hence, the use of this strategy is appropriate and useful in initiating a conversation. For example, in (12), an English manager asks his staff about his previous action before raising the main topic of the talk.

(12) Manager: Where you been?

Staff: Hi. Um... Getting drug tested, actually.

Manager: The deposition's this afternoon. Before they get here, I want you to grill this woman about her background for anything they might use against her. You got it?

[Suits, season 1, episode 1 - 58:08]

4.4. The rarely used strategies by English and Vietnamese subjects

Among strategies rarely employed, some are used by both subjects, some only by English subjects and some only by Vietnamese ones. In the first place, the group of strategies utilized by both subjects includes asking confirmation question, talking about current task, referring to external circumstances/ objects and apologizing. Factually, these strategies are only present in one or two conversations in both languages, except for the strategy of confirmation question that appear in four Vietnamese conversations. From their rare appearance, it can be inferred that it is not habitual for both subjects to make use of these strategies in initiating a conversation. Despite their exceedingly rare appearance, these strategies have particular meanings. For example, English parties use the strategy of asking confirmation question not to ask for information but just to inform their presence as in example (13) below.
(13) Staff:
You wanted to see me?
Manager:
Did you go see Joy after I told you not to?

[Suits, season 1, episode 5-24:34] 
Thanks to the confirmation question "you wanted to see me?", the staff can get the manager's attention and inform him about his coming. Unlike English subjects, Vietnamese subjects do not make use of this strategy to get the other's attention but to help their interlocutors raise the main topic as in (14).

$\begin{array}{ll}\text { (14) Staff: } & \text { (Knock at door) } \\ \text { Manager: } & \begin{array}{l}\text { Mời vào! } \\ \text { "Come in, please!" }\end{array} \\ \text { Staff: } & \begin{array}{l}\text { Anh Thiết. } \\ \text { "Mr. Thiet." }\end{array} \\ \text { Manager: } & \begin{array}{l}\text { Chào anh. } \\ \text { "Hello." }\end{array} \\ \text { Staff: } & \begin{array}{l}\text { Anh cho gọi tôi à? } \\ \text { "You wanted to see me?" } \\ \text { Manager: }\end{array} \\ & \text { Vâng, mời anh ngồi........ } \\ & \text { "Yes, sit down, please!" }\end{array}$

[Đối thủ kỳ phùng, episode 29 - 5:40]

As seen in (14), because the confirmation question is produced after several exchanges such as summons-answer, invitation of coming in and greeting, its function is not to get the other's attention. Factually, the confirmation question "Anh gọi cho tôi à?" performed by the staff can be understood as "I'm here and what you want to talk to me". As usual, this strategy helps the other interlocutor to initiate the main topic of the talk right after it.

Furthermore, the strategies of talking about current task, referring to external circumstances/objects and apologizing can be exploited as a hint for initiating a conversation. These strategies can be regarded as phatic communication which helps the conversation proceed smoothly. Vietnamese subjects often make use of these strategies to maintain participants' relationship or to avoid an abrupt opening. However, English subjects utilize these strategies to get the other's attention or to lead in the main topic. For example, a party may talk about a current task which his/ her interlocutor is doing as in (15) or refer to an external object as in (16).
(15) Staff: $\quad$ Anh ạ.

"Hello."

Manager: Ờ, cậu đang làm số mới đấy à? "Yes. You are printing the new issue?"

Staff: Vâng ạ. "Yes."

Manager: Mấy giờ thì ra phim? "When will the film be coated?"

Staff: Báo cáo anh 11 rưỡi.

"11:30, sir."

Manager: À̀, cậu đưa lại cho tôi bài viết về công ty Hoàng Quân

"Ah, give me the article on Hoang Quan Company"

[Cảnh sát hình sự - Chạy án, season 1, episode 6-23:50]

(16) Manager: What's that? (Looking at the newspaper the staff is holding)

Staff: It's an article where Clifford Danner took his plea. Do you want me to read it to you?

Manager: No.

Staff: Clifford Danner had a history of violence.

[Suits (season 1, episode 12-6:11]

It can be seen that in (15), the Vietnamese manager knows that his staff is printing a new issue, but he still asks "Cậu đang làm số mới đấy à?" After this question, the staff and manager exchange several turns relating to the staff's current task before the manager initiates the topic of concern. The exchanges on the current task in (15) function as phatic communication which helps the conversation to be raised more smoothly. Differently, in (16), an English staff makes use of a newspaper as an external object to open a topic with his manager. The staff is holding a newspaper, standing by the door and when the manager comes in, she asks him "what's that?" with the reference to the newspaper he is holding. Thanks to the newspaper, the staff is successful in getting the manager's attention and raises the topic of concern appropriately. 
In the second place, the group of strategies only utilized by English subjects includes asking for the other's availability for talking, talking about the third person and offering the help. The act of asking for the other's availability for talking is a polite way of initiating a conversation. Normally, this strategy is used by English staff - the partners of lower status to ask for the permission from the managers - the partners of higher status to have a conversation with him. Example (17) displays the way this strategy is employed.

(17) Staff: Mr. Vice President, do you have a moment?

Manager: I'm sorry. The President asked to see me.

Staff: $\quad$ No, he didn't. You requested the meeting, and I took it off the schedule.

[House of cards, season 2, episode 8 - 27:13]

In (17), the question "do you have a moment?" is not to find out whether the manager is busy or not, but it is to ask for the manager's permission for talking with him. The negative politeness strategy is exploited in this situaiton because the staff does not want to make an imposition on the manager. Instead, the staff lets the manager decide whether to talk to him or to go away.

In the last place, the group of rarely used strategies by Vietnamese subjects includes referring to self and talking about life at home. In Vietnamese culture, these two strategies are regarded as phatic communication and only often employed by participants of close relationship. Referring to self is utilized to talk about the speaker's health or feelings while talking about life at home is to ask about participants' personal life. Normally, Vietnamese people only reveal their health status or feelings and personal life at home to their relatives or close friends. However, examined conversations are between a staff and his/ her manager and occur in office settings, which leads to the low frequency of occurrence of these two strategies. The utilization of referring to self can be illustrated in example (18) below.

(18) Staff: Chị ơi!

$$
\text { "Hey, sister!" }
$$

\section{Manager: Chị đau đầu quá, gì hả em?}

"I have a headache. What's up?"

[Mưa bóng mây, episode 20-4:00]

Customarily, the issues of health and feelings are only told to the members of family or close friends. However, in this situation, the manager expresses her health problem to her staff when initiating a conversation. This strategy, in this situation, creates a special effect on the talk. Thanks to it, the manager wants to convey that she regards the staff as her relative or her close friend. In this way, not only the purpose of the interaction can be achieved but also participants' relationship can be maintained and promoted.

\section{Conclusions}

The results display that English and Vietnamese subjects share slight similarities but make notable differences in the way they employ their verbal strategies to open a conversation in office settings. From the findings, it can be concluded that there emerge three significant differences in the ways English and Vietnamese subjects initiate a conversation in office settings. First of all, in contrast to English subjects, Vietnamese ones create a much lengthier and more complicated opening with the utilization of more number of verbal strategies. As indicated, on average, to open a conversation, Vietnamese subjects take at least two strategies while English ones need only one strategy. Typically, a Vietnamese opening section follows several turns of exchanges before the main topic is initiated. Example (11) illustrated above can be regarded as a typical opening of Vietnamese subjects. In (11) the staff and manager produce some turns of exchanges such as invitation of coming in, greeting, invitation to sit down, offering a drink, 
referring to the other's state before raising the main topic of the conversation. Inversely, English subjects have a tendency to initiate the topic of concern right after they get attention from their interlocutors. Despite a wide range of verbal strategies, English subjects may choose such as greeting, calling out their name, asking confirmation questions, asking about current activities and so on, their purpose is just to get the other's attention. This indicates that unlike Vietnamese subjects, English ones tend to initiate a conversation in a straightforward manner. In other words, while Vietnamese subjects are roundabout and indirect to avoid an abrupt or hasty opening, English ones attempt to build a brief opening with great focus on the effectiveness of the work.

Additionally, besides the difference in the number of strategies exploited, the distribution of each strategy is exceedingly different in the two languages. To initiate a conversation, Vietnamese subjects tend to utilize the strategies of greeting and topic initiation while English ones prefer calling the other's title/ name. As illustrated, the strategy of calling the other's title/ name by English subjects is just to get the other's attention. Nevertheless, the strategy of greeting is to express the politeness and respect towards the others while the strategy of topic initiation is just to make the act of raising a topic lengthier and less abrupt. Furthermore, after some ritual exchanges like greeting or calling the others' names or titles with the aim to get the others' attention, some phatic exchanges may be produced before the main topic is raised. These phatic exchanges are mainly work-oriented with inquiries and responses on current or previous tasks by English subjects but chiefly rapport-oriented with concern on interlocutor's feelings, health, clothes, travelling, life at home by Vietnamese subjects. The over-exploitation of greeting and topic initiation strategies in combination with rapport-oriented phatic exchanges suggests that in the process of opening a conversation, Vietnamese subjects attempt to both exchange information and maintain the rapport between participants. Inversely, the focus on getting the other's attention combined with work-oriented phatic exchanges indicates that English subjects just target at exchanging information rather maintaining their relationship.

Finally, unlike English subjects, through the employment of verbal strategies, Vietnamese staff and managers reveal a close but respectful relationship. On the one hand, although these examined conversations are between staff and managers in office settings and discuss workrelated issues, Vietnamese subjects make use of kinship terms such as "chú", "anh", "chị”, "cháu", "em" in most opening sections. The use of a variety of kinship terms which are polite rituals of the Vietnamese helps increase the intimacy between parties by regarding them as members of their family and express the hierarchy between two parties (Trần Ngọc Thêm, 1999, p. 159). On the other hand, in initiating a conversation, the staff - the partners of lower status show respect towards the managers - the partners of higher social status via the use of such polite particles as "dạ" and "ạ" and performative verbs such as "báo cáo", "trình bày", "thưa". Via this exploitation, the power distance between Vietnamese staff and managers is rather obvious. On the contrary, instead of utilizing polite particles and kinship terms, English subjects call the others' titles or names directly. This can suggest that English subjects may not care about maintaining rapport in the process of opening a conversation, they mostly concentrate on raising the topic of concern.

In conclusion, the paper yields the findings and discussions on verbal strategies used by English and Vietnamese staff and managers in initiating a conversation in office settings. The similarities and differences in the utilization of each verbal strategy by both 
subjects are deliberated. The study is hoped to help Vietnamese learners and users to initiate a conversation with English native speakers smoothly, effectively and politely.

\section{References}

\section{Vietnamese}

Trần Ngọc Thêm (1999). Cơ sở văn hóa Việt Nam. Tp. Hồ Chí Minh: Nhà xuất bản Giáo dục.

Phạm Văn Tình (2000). Định hướng giao tiếp của các phát ngôn chào hỏi trong tiếng Việt. Kỷ yếu Hội thảo Thành tố văn hoá trong dạy học ngoại ngũu. Hội Ngôn ngữ học Việt Nam và Trường Đại học Ngoại ngữ - Đại học Quốc gia Hà Nội, tr. 225-228.

\section{English}

Duranti, A. (1992). Language and bodies in social space: Samoan ceremonial greetings. American Anthropologist, 94(3), 657-691.

Firth, R. (1972). Verbal and bodily rituals of greeting and parting. pp. 1-38 in J. S. La Fontaine (ed.). The interpretation of ritual: Essays in honour of A. I. Richards. London: Tavistock Publications Ltd.

Goffman, E. (1963). Behavior in public places: Notes on the social organization of gatherings. New York: The Free Press.

Kendon, A. (1977). Studies in the behavior of social interaction. Lisse: Peter De Ridd Press.

Kendon, A. \& Ferber, A. (1973). A description of some human greetings. In P. M. Michael \& J. H. Cook
(Eds.). Comparative ecology and behavior of primates. London: Academic Press.

Krivonos, P. D. \& Knapp, M. L. (1975). Initiating communication: What do you say when you say hello? Central States Speech Journal, Vol. 26, 115-125.

Maynard, D. W. \& Zimmerman, D. H. (1984). Topical talk, ritual and the social organization of relationships. Social Psychology Quarterly, 47(4), 301-316.

Omar, A. (1989). How learners greet and take leave in Kiswahili. Unpublished manuscript, Indiana University.

Omar, A.S. (1992). Conversational Openings in Kiswahili: The Pragmatic Performance of Native and Non-native Speakers. Pragmatics and language learning, Vol. 3, 20-32.

Pillet-Shore, M. D. (2008). Coming Together: Creating and Maintaining Social Relationships through the Openings of Face-to-Face Interactions. Unpublished Ph.D. dissertation. Department of Sociology, University of California, Los Angeles.

Schegloff, E. A. (1968). Sequencing in Conversational Openings. American Anthropologist 70, 1075-1095.

Schegloff, E. A. (1986). The routine as achievement. Human Studies, Vol. 9, 111-151.

Schiffrin, D. (1977). Opening encounters. American Sociological Review, Vol. 42, 679-691.

Tram, N. (2002). Conversational openings in English and Vietnamese: Developing pragmatic awareness for learners. M.A. Thesis. Danang.

Youssouf, I. A., Grimshaw, A. D. \& Bird, C. S. (1976). Greetings in the desert. American Ethnologist, Vol. $3,797-824$.

\title{
CHIẾN LƯợC NGÔN TƯ ĐƯợC SỬ DỤNG BỞI NHÂN VIÊN VÀ NGƯỜI QUẢN LÝ ĐỂ KHAI THOẠI Ở VĂN PHÒNG TRONG TIÊNG ANH VÀ TIẾNG VIẸT
}

\author{
Hoàng Trà $\mathrm{My}$ \\ Trường Đại học Xây dựng Miền Trung, Nguyễn Du, Tuy Hòa, Phú Yên, Việt Nam
}

Tóm tắt: Trong giao tiếp, một khai thoại phù hợp sẽ giúp tạo ấn tượng tốt và tăng hiệu quả của cuộc thoại; tuy nhiên, rất khó tạo ra một khai thoại lịch sự. Do đó, nghiên cứu này nhằm tìm ra và miêu tả những chiến lược ngôn từ được sử dụng bởi nhân viên và người quản lý trong khai thoại ở tiếng Anh và Việt. Phương pháp phân tích nội dung định tính được sử dụng để phân tích 120 đoạn thoại trên phim (60 Anh và 60 Việt). Kết quả chỉ ra rằng đối tượng Việt sử dụng nhiều chiến lược mở thoại hơn đối tượng Anh. Đặc biệt, khi khai thoại, đối tượng Anh có vẻ giữ khoảng cách với những trao đổi về công việc nhưng đối tượng Việt lại thể hiện sự gần gũi và tôn trọng với những trao đổi nhằm gìn giữ mối quan hệ.

Tù khóa: khai thoại, chiến lược khai thoại, chiến lược ngôn từ, chiến lược ngôn từ trong khai thoại, phân tích nội dung 